\title{
TANGGAP BENCANA MAHASISWA KKN STIBA MAKASSAR MELALUI PEMBINAAN ROHANI MASYARAKAT DESA KABIRAAN KABUPATEN MAJENE
}

\section{DISASTER RESPONSE OF KKN STIBA MAKASSAR STUDENTS THROUGH COMMUNITY SPIRITUAL DEVELOPMENT IN KABIRAAN VILLAGE MAJENE REGENCY}

\author{
Aswar \\ Sekolah Tinggi Ilmu Islam dan Bahasa Arab (STIBA) Makassar \\ Email: aswar@stiba.ac.id

\section{Iskandar} \\ Sekolah Tinggi Ilmu Islam dan Bahasa Arab (STIBA) Makassar \\ Email: iskandarkato@stiba.ac.id

\section{Syandri} \\ Sekolah Tinggi Ilmu Islam dan Bahasa Arab (STIBA) Makassar \\ Email: syandri@stiba.ac.id
}

\begin{tabular}{ll}
\hline Keywords : & \multicolumn{1}{c}{ ABSTRACT } \\
KKN, Humanity, STIBA & The purpose of STIBA Makassar Real Work Lecture (KKN) with \\
the concept of "KKN Kemanusiaan of West Sulawesi" is to \\
realize community service which is a pillar of "Tri Darma \\
Perguruan Tinggi". The method of implementing this program is \\
to map the problem using SOAR analysis. After analyzing the \\
problems and needs of the community, several appropriate work \\
programs are prepared. Successful work programs are Dirosah \\
Method of Al-Qur'an Learning, Weekly Taklim, Community \\
Service, Tablig Akbar, TK/ TPA, Clean Friday, and others. The \\
results of the activities showed that STIBA students are able to \\
serve the people affected by the disaster seriously so that they get \\
a lot of social experience. The community of Ulumanda, \\
especially in Kabiraan village, feel very helped by the presence \\
of students during KKN there and fully support the \\
implementation of "KKN Kemanusiaan STIBA Makassar" for the \\
recovery of the state of the community after the earthquake \\
disaster. All parties expect the sustainability of KKN activities in \\
terms of construction both formally and non-formally for \\
Kabiraan village.
\end{tabular}




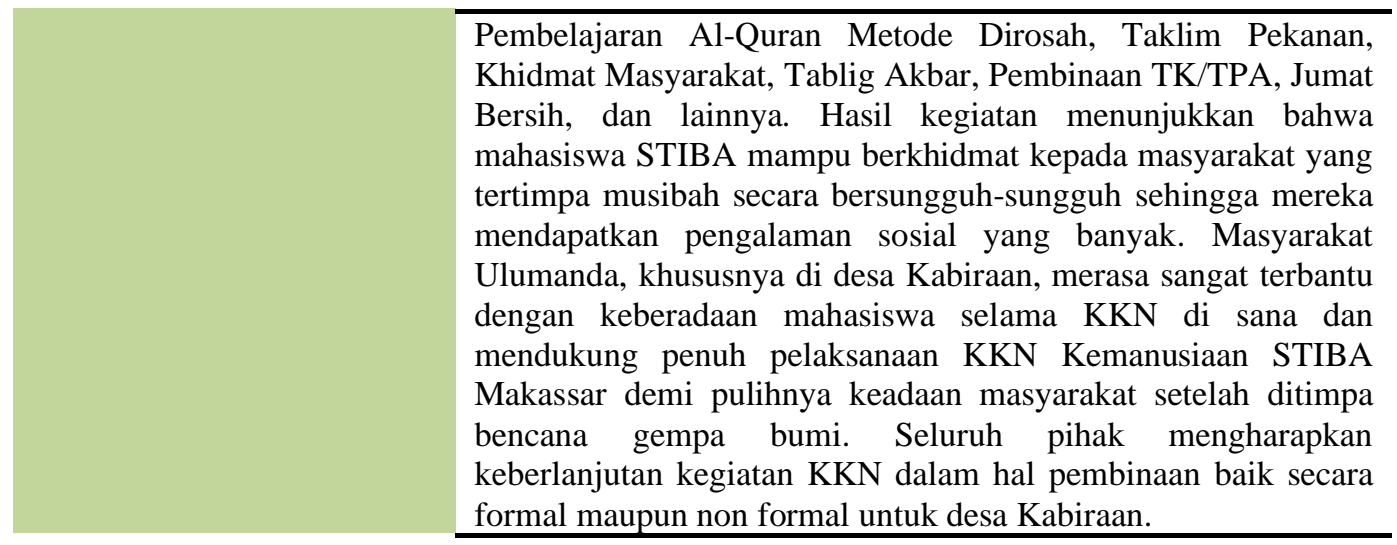

Diterima: 18 Oktober 2021; Direvisi: 14 Desember 2021; Disetujui: 14 Desember 2021; Tersedia online: 31 Desember 2021

How to cite: Aswar, Iskandar, Syandri "Tanggap Bencana Mahasiswa KKN STIBA Makassar Melalui Pembinaan Rohani Masyarakat Desa Kabiraan Kabupaten Majene", WAHATUL MUJTAMA': Jurnal Pengabdian Masyarakat Vol. 2, No. 2 (2021): 125-135. doi: 10.36701/wahatul.v2i2.442.

\section{PENDAHULUAN}

Kondisi Desa Kabiraan adalah daerah pedesaan yang berada didaerah pegunungan dengan ketinggian 400 s.d. 450 dpl dan mempunyai luas wilayah 18 $\mathrm{km}^{2}$ yang terdiri atas 9 Dusun dan 10 Rukun Tetangga (RT). Sejak tahun 1969, untuk pertama kalinya dibentuk desa tersebut, sekaligus diselenggarakan pemilihan Kepala Desa pertama. Kabiraan berasal dari kata dasar "bira" yang berarti "batas" yakni batas antara kerajaan (Tomakaka) Lombang yang sekarang menjadi Desa Sambabo. Desa Kabiraan berada di Kecamatan Ulumanda, Kabupaten Majene, Provinsi Sulawesi Barat. Desan ini berbatasan dengan Desa Lombang Timur di sebelah utara, Desa Sambabo di sebelah selatan, Desa Sulai di sebelah barat, dan Desa Tadeallo di sebelah timur. Des aini memiliki 1383 jiwa penduduk, yang terdiri dari 624 jiwa penduduk erempuan dan 759 jiwa penduduk laki-laki. ${ }^{1}$

Untuk Tingkat Pendidikan di Desa Kabiraan, sebagian penduduknya tamat SMP dan sebagian telah melanjutkan studinya ke perguruan tinggi baik di wilayah Sulawesi Barat, Sulawesi Selatan, Jawa, bahkan sampai ke luar negeri, karena kesadaran masyarakat dalam hal pendidikan untuk mendorong anak-anak melanjutkan sekolah ke jenjang yang lebih tinggi cukup tinggi. Mata pencaharian penduduk Desa Kabiraan didominasi oleh petani, peternak, Pegawai Negeri Sipil, Pedagang, Buruh Tani dan karyawan Swasta. Jenis usaha yang ada di Desa Kabiraan di antaranya peternakan kambing, peternakan sapi, dan pembuatan kusen. Selain itu, juga terdapat warung kelontong, counter $H P$, bengkel motor, dan

1 Nomor. Net. Desa Kabiraan 91454. https://www.nomor.net/_kodepos.php?_i=desakodepos\&sby=000000\&daerah=Desa-Ulumanda\%20(Ulumunda)-Kab.-Majene\&jobs=Kabiraan 
lainnya. Untuk aspek pemerintahan, Desa Kabiraan menganut sistem kelembagaan pemerintahan desa demokrasi yang berazaskan Pancasila dan UUD 1945. ${ }^{2}$

Dengan melihat kondisi daerah dan masyarakat di Desa Kabiraan, dapat disimpulkan bahwa sebagian besar masyarakatnya berada pada kondisi perekonomian pra sejahtera. Hal ini karena desa berada pada daerah pegunungan dan sebagaian besar masyarakat berprofesi sebagai petani. Pada strata pendidikan masyarakat, perhatian masyarakat pada pendidikan semakin meningkat. Terlihat bahwa pemuda maupun pemudi tetap bisa mengupayakan sekolah di Perguruan Tinggi meskipun jauh dari pusat kota.

Gempa yang menimpa wilayah Sulawesi Barat pada tanggal 15 Januari 2021 lalu, khususnya daerah Majene dan Mamuju, menyisakan banyak kerugian, baik materi maupun non materi. Musibah ini menyisakan kesedihan yang mendalam bagi warga masyarakatnya. Ratusan rumah warga rubuh dan ambruk sehingga banyak korban menempati tenda-tenda darurat yang disiapkan oleh para relawan.

Berdasarkan data Basrnas Mamuju, korban jiwa di Kabupaten Majene sebanyak 10 orang dan di Kabupaten Mamuju sebanyak 95 orang, sehingga total korban jiwa mencapai 105 orang. Sementara jumlah korban luka-luka akibat gempa di dua wilayah tersebut sebanyak 3369 orang dan yang terpaksa harus mengungsi sejumlah 89524 orang. Kerugian material di Kabupaten Majene berupa satu kantor Danramil rusak, 17 fasilitas kesehatan, 4122 rumah, dan sebanyak 32 fasilitas ekonomi dan perkantoran rusak. Sementara di Kabupaten Mamuju sebanyak 3741 rumah rusak, kantor Gubernur, 5 unit fasilitas kesehatan, 3 jembatan rusak dan satu pelabuhan. ${ }^{3}$

Kondisi masyarakat pasca gempa bumi sebagian besar masih menempati tenda-tenda darurat karena masih ada gempa susulan yang membuat masyarakat panik dan trauma bertambah. Donasi kebutuhan pokok terus mengalir dari berbagai penjuru. Beberapa relawan juga menempati posko-posko tertentu di setiap titik gempa. Keberadaan relawan di lokasi bencana selain untuk menyalurkan bantuan dari para donator, juga melakukan trauma healing pada posko-posko pengungsi yang ada. Keberadaan para relawan ini sangat membantu masyarakat, baik dalam pemenuhan kebutuhan mereka maupun mengikis trauma mereka dengan kegiatankegiatan yang bermanfaat.

Jumlah relawan yang ada, belum mampu memenuhi kebutuhan pengungsi di beberapa titik bencana. Para relawan dari berbagai daerah datang bergantian untuk membantu masyarakat. Melihat kebutuhan korban gempa di wilayah Sulawesi Barat terus meningkat, Sekolah Tinggi Ilmu Islam dan Bahasa arab (STIBA) Makassar berinisiatif mengutus beberapa mahasiswa maupun mahasiswi Kuliah Kerja Nyata (KKN) dalam program yang bertajuk "KKN Kemanusiaan Sulawesi Barat".

${ }^{2}$ Wikipedia. Ulumanda, Majene. https://id.wikipedia.org/wiki/Ulumanda, Majene (Diakses pada tanggal 14 Desember 2021).

${ }^{3}$ Zulfiah Sam, Saadal Jannah, Sartini Lambajo, "Pelaksanaan KKN Kemanusiaan Mahasiswi STIBA Makassar di Kelurahan Malunda, Kabupaten Majene", WAHATUL MUJTAMA': Jurnal Pengabdian masyarakat 2. No. 2, (2021): 1-10. 
Berdasarkan uraian di atas, dirumuskan beberapa tujuan program tersebut, yaitu: (1) untuk melaksanakan Tri Darma Perguruan Tinggi khususnya dalam bentuk pengabdian kepada masyarakat $(\mathrm{PkM})$; (2) untuk berperan aktif sebagai relawan kemanusiaan dalam upaya mengatasi masalah pasca gempa; dan (3) untuk menyediakan wadah bagi mahasiswa dalam mendapatkan pengalaman sosial dalam dakwah dan pengabdian kepada masyarakat.

Adapun KKN merupakan suatu bentuk pengabdian kepada masyarakat yang dilakukan oleh mahasiswa. Pelaksanaan KKN diharapkan dapat meningkatkan empati mahasiswa dan memberikan sumbangan penyelesaian persoalan yang ada di masyarakat. Sebagai kegiatan intrakurikuler, KKN merupakan bagian integral dari kurikulum program studi yang diharapkan dapat meningkatkan kecerdasan intelektual, emosional, dan sosial. ${ }^{4}$

Adapun metode yang digunakan dalam kegiatan KKN Kemanusiaan adalah metode analisis SOAR yang dijabarkan sebagai berikut:

1. Strenght, antusias besar masyarakat untuk aktif dalam kegiatan keagamaan yang menjadi salah satu alternatif dalam upaya trauma healing pasca gempa.

2. Opportunites, dukungan penuh pemerintah setempat dan kerja sama serta pengarahan dari lembaga dakwah yang ada di wilayah tersebut.

3. Aspiration, sebagian besar masyarakat masih awam dengan dengan dasar-dasar keislaman dan baca tulis Al-Qur'an. Sehingga dengan kegiatan ini, kebutuhan pembinaan keagamaan masyarakat secara intensif mampu dimaksimalkan.

4. Result, dapat terwujud masyarakat islami yang beriman dan berakhlaq mulia.

Dari hasil analisis di atas, dirumuskan beberapa program kerja, yaitu pembelajaran Al-Qur'an dengan metode Dirosah, Taklim Pekanan, Khidmat Masyarakat, Tablig Akbar, Pembinaan TK/TPA, dan Pembuatan Papan Nama Imam Desa dan Batas Antardusun.

Sejumlah kegiatan PkM terdahulu yang relevan dengan pelaksanaan KKN Kemanusiaan STIBA Makassar adalah sebagai berikut:

1. PkM yang dilakukan oleh Zulfiah Sam, Saadal Jannah dan Sartini Lambajo dengan judul "Pelaksanaan KKN Kemanusiaan Mahasiswi STIBA Makassar di Kelurahan Malunda, Kabupaten Majene". Kegiatan ini merupakan bagian lain dari KKN Kemanusiaan STIBA Makassar yang dilaksanakan oleh para mahasiswi KKN di Kelurahan Malunda. Kegiatan ini bekerjasama dengan Muslimah Wahdah Islamiyah Daerah Majene. Beberapa program kerja yang berhasil dilaksanakan di beberapa titik pengungsian adalah bakti sosial, pengajaran Al-Qur'an orang dewasa maupun anak-anak, taklim fikih muslimah, Daurah Ramadan Muslimah, pengajaran Bahasa Arab untuk anakanak, taklim remaja, tahfiz Al-Qur'an, dan Festival Anak Saleh di Desa Lombang. Hasil dari kegiatan ini adalah memberikan kontribusi yang sangat signifikan bagi pemerintah setempat dalam mengatasi permasalahn yang timbul akibat bencana berupa penanganan aspek spiritual para korban bencana sebagai salah satu bentuk trauma healing pasca bencana. Kegiatan ini juga

4 Dodik Eko Prakoso, "Laporan Akhir Kuliah Kerja Nyata (KKN) Desa Purwasaba Kecamatan Mandiraja Kabupaten Banjarnegara", Prodi Televisi dan Film Fakultas Seni Rupa dan Desain Institut Seni Indonesia Surakarta (2016). 
mampu mengasah dan meningkatkan kepekaan sosial dan dakwah mahasiswa sebagaimana terlihat dalam kesungguhan dan komitmen mereka dalam berkhidmat kepada masyarakat. ${ }^{5}$

2. PkM yang dilaksanakan oleh Mohammad Bachruddin Yusuf dalam Laporan Pengabdian Masyarakat Kuliah Kerja Nyata (KKN) yang berjudul "Tanggap Bencana Alam di Dusun Sijati, Desa Sawangan, Kabupaten Porwerejo, Provinsi jawa Tengah". Kegiatan KKN ini merancang program kerja Tanggap Bencana Alam kepada Warga Dusun Sijati. Program ini dilaksanakan dengan memahamkan masyarakat tentang bahaya dan dampak dari bencana alam, serta memberikan tanda jalur evakuasi jika terjadi bencana alam. Hal ini dilakukan agar ke depannya masyarakat tanggap dan siap dalam menghadapi bencana alam. Hasil dari kegiatan ini adalah warga dusun Sijati mampu mengetahui cara merawat, menghadapi, dan evakuasi pada saat sebelum, saat terjadi, dan setelah terjadi bencana alam. ${ }^{6}$

3. PkM yang dilaksanakan oleh mahasiswa KKN Universitas Bangka Belitung dengan menjadi relawan Covid-19 di Kelurahan Bukit Betung. Pengabdian ini bertujuan untuk mengedukasi masyarakat akan pencegahan penyebaran virus Covid-19, serta memberikan konseling yang dibutuhkan dalam upaya pengembangan potensi masyarakat. program ini berjalan lancar dan sukses dengan beberapa program seperti pembuatan desinfektan dan hand sanitizer secara gratis. ${ }^{7}$

Beberapa program PkM yang telah disebutkan di atas menunjukkan bahwa program KKN Kemanusiaan sejatinya telah dilakukan dengan berbagai macam program yang dianggap penting untuk masyarakat. Adapun kegiatan KKN Kemanusiaan oleh Mahasiswa di Desa Kabiraan Kelurahan Ulumanda lebih fokus pada pembinaan Islami masyarakat, khususnya kaum muslimin dan anak-anak.

\section{PEMBAHASAN}

Kelurahan Ulumanda merupakan salah satu wilayah yang berdampak cukup parah. Bahkan sebagian titik sempat terisolir karena medan rusak akibat gempa. Masalah ini tentunya menyisakan duka dan trauma yang sangat dalam bagi masyarakatnya. Kehadiran mahasiswa KKN STIBA Makassar diharapkan dapat mengikis trauma mereka melalui pembinaan keislaman secara intensif. Sebelum kedatangan mahasiswa KKN, beberapa relawan dari beberapa daerah telah dating silih berganti. Mereka banyak membantu masyarakat dalam pengadaan dapur umum, evakuasi korban, pelayanan kesehatan, pembenahan beberapa rumah-rumah

${ }^{5}$ Zulfiah Sam, Saadal Jannah, Sartini Lambajo, "Pelaksanaan KKN Kemanusiaan Mahasiswi STIBA Makassar di Kelurahan Malunda, Kabupaten Majene", WAHATUL MUJTAMA': Jurnal Pengabdian masyarakat 2. No. 2, (2021): 1-10.

${ }^{6}$ Mohammad Bachruddin Yusuf, "Tanggap Bencana Alam di Dusun Sijati, Desa Sawangan, Kabupaten Porworejo, Provinsi Jawa Tengah" Laporan Pengabdian Masyarakat Kuliah Kerja Nyata (KKN) Pusat Kuliah Kerja Nyata Direktorat Penelitian dan Pengabdian Masyarakat Universitas Islam Indonesia Yogyakarta, 2017.

${ }^{7}$ Sindy Ayu Kirana dan Refy Safitri, "Pengabdian KKN Keluarahan Bukit Betung Menjadi Relawan Covid-19 di Wilayah Bangka Belitung", Prosiding Seminar Hukum dan Publikasi Nasional (Serumpun) II 2 (2020): 461-470. 
warga yang rusak dan pembangunan tenda-tenda darurat. Oleh karena itu, untuk melanjutkan perjuangan para relawan, dilaksanakan beberapa program berikut:

\section{Pembelajaran Al-Qur'an dengan Metode Dirosah}

Kegiatan ini diawali dengan sosialisasi kepada masyarakat di setiap masjid yang ada di Desa Kabiraan, dengan meperkenalkan metode simpel belajar AlQur'an bagi orang dewasa yang tidak memiliki banyak waktu luang untuk belajar Al-Qur'an. Mahasiswa bertanggung jawab di setiap masjid yang telah ditentukan sebagai pengajar untuk membina halaqah Dirosa kepada jemaah yang ingin ikut belajar. Faktor pendukung berjalannya kegiatan ini adalah semangat masyarakat untuk belajar membaca Al-Qur'an dan dukungan pemerintah desa dan tokoh masyarakat setempat untuk kegiatan ini. Adapun kendala dalam kegiatan ini adalah kurangnya ketepatan waktu antara mahasiswa dan masyarakat yang mau belajar, karena mayoritas masyarakat di Desa Kabiraan berprofesi sebagai petani dan jarak antara posko dan beberapa tempat mengajar berjauhan sehingga mahasiswa terkendala alat transportasi. Solusinya, mahasiswa terkadang meminjam kendaraan masyarakat. Kegiatan belajar Al-Qur'an dengan metode Dirosa ini berjalan lancer. Masyarakat yang dulunya masih terbata-bata dalam membaca, kini sudah lebih baik. Mulai dari penyebutan makhraj huruf, tajwid dan yang lainnya. Namun karena singkatnya waktu KKN yang hanya berjalan sekitar 1 bulan, beberapa halaqah tidak terselesaikan pembelajarannya. Adapun solusinya, halaqah yang belum selesai pembelajarannya akan diambil alih oleh dai dari Dewan Pimpinan Cabang (DPC) Wahdah Islamiyah Ulumanda.

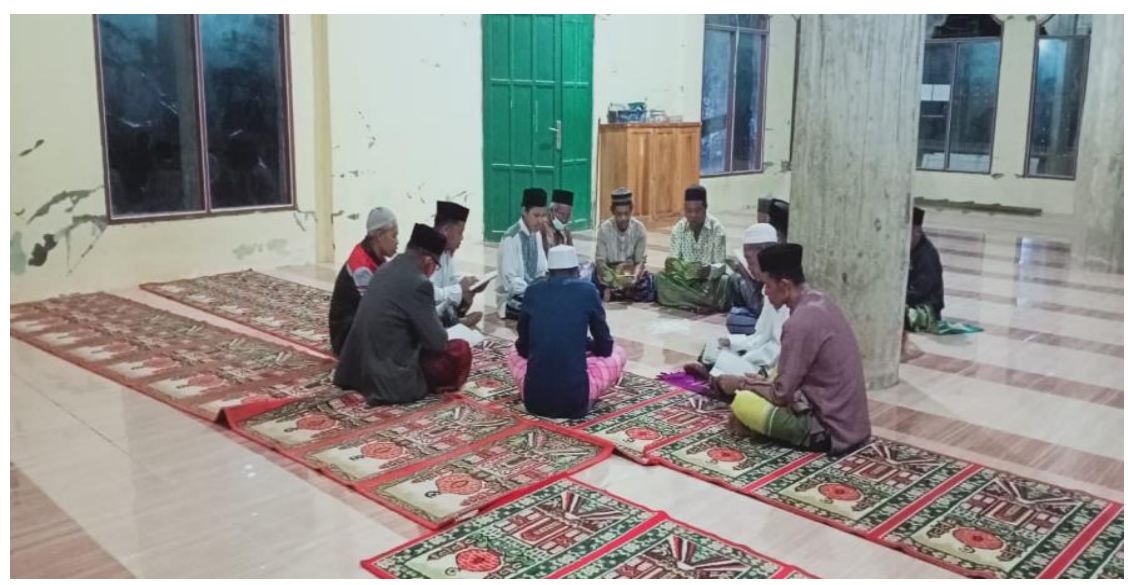

Gambar 1. Kegiatan Belajar Al-Qur'an dengan Metode Dirosa

\section{Taklim Pekanan}

Taklim Pekanan adalah kegiatan menyampaikan ceramah/nasehat kepada masyarakat di Desa Kabiraan setiap pekan. Metode yang digunakan adalah mahasiswa menyampaikan materi seputar agama Islam (tematik) di masjid dan setiap mahasiswa diberikan jadwal tetap. Pengalaman menarik yang dirasakan mahasiswa adalah kurang percaya diri untuk tampil di depan umum karena selama di kampus beberapa mahasiswa sama sekali belum pernah tampil berbicara di depan 
umum sehingga terkadang ada beberapa mahasiswa yang masih gugup dalam menyampaikan materinya. Adapun solusinya, setiap mahasiswa diberikan jadwal khusus dan diminta untuk mempersiapkan materi dengan sebaik-baiknya. Faktor pendukung dalam kegiatan ini adalah antusiasme dan dukungan masyarakat terhadap kegiatan ini. Kegiatan ini juga menjadi wadah silaturahmi antara masyarakat dan mahasiswa. Perubahan yang terjadi pada masyarakat Desa Kabiraan setelah mengikuti kegiatan ini adalah bertambahnya ilmu pengetahuan masyarakat tentang agama dan masyarakat semakin paham dengan perintah dan larangan Allah swt. Masyarakat juga semakin paham tentang hakikat hidup di dunia yang hanya sementara dan akhirat adalah sebaik-baik kehidupan yang kekal. Gambaran masyarakat sebelum mahasiswa KKN datang adalah kurangnya pengetahuan masyarakat seputar dasar-dasar ilmu agama, masyarakat sangat jarang mendengarkan ceramah seputar agama Islam, karena kurangnya dai di desa tersebut sehingga banyak masyarakat kesulitan belajar ilmu agama.

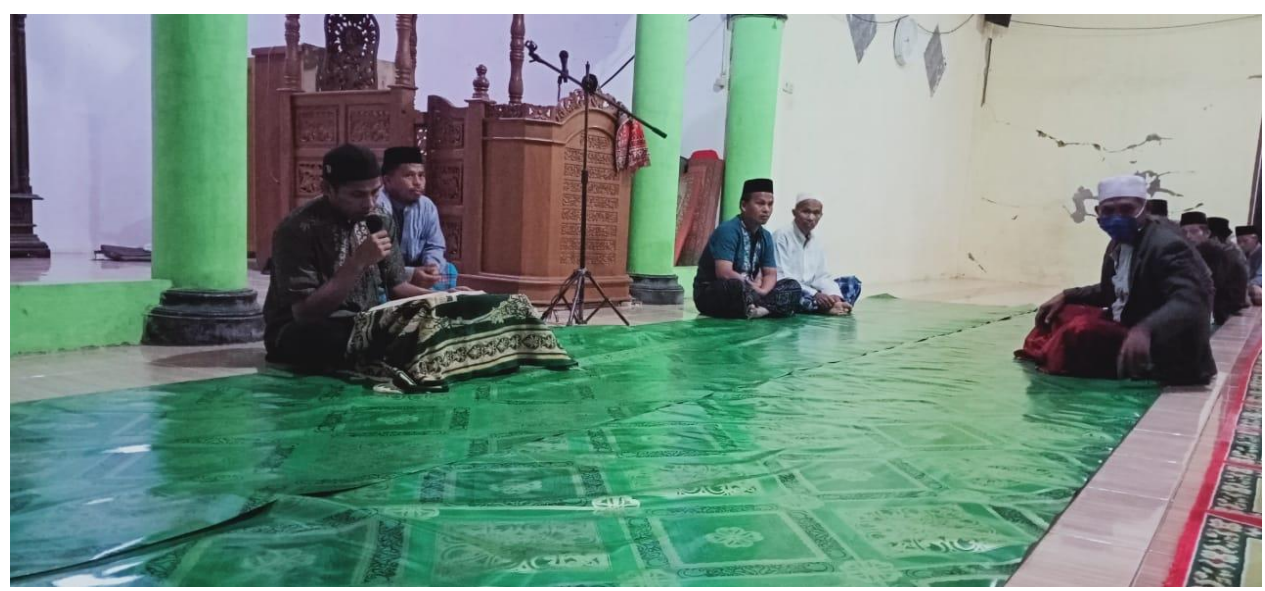

Gambar 2. Taklim Pekanan

\section{Khidmat Masyarakat}

Gempa bumi yang meluluhlantakkan Sulawesi Barat menyebabkan perekonomian mati total. Banyaknya rumah dan bangunan-bangunan vital yang hancur menjadikan program ini termasuk program utama mahasiswa KKN Kemanusian Sulawesi Barat terkhusus di Desa Kabiraan. Kegiatan ini diawali dengan melakukan silaturrahmi ke rumah-rumah masyarakat yang terdampak gempa yang ada di Desa Kabiraan setiap pagi harinya. Kemudian menawarkan bantuan kepada masyarakat yang membutuhkan bantuan, seperti memperbaiki rumah, membersihkan puing-puing bangunan dan sebagainya. Dalam kegiatan ini juga terkadang diselipkan dengan agenda lain, seperti sosialisasi program Dirosa. Agenda ini berjalan dengan baik dan rutin dilaksanakan setiap hari. Faktor pendukungnya adalah terbukanya masyarakat terhadap mahasiswa $\mathrm{KKN}$ dan terkadang konsumsi untuk mahasiswa disiapkan langsung oleh masyarakat. Adapun kendala yang didapatkan adalah terbatasnya jumlah personil dari mahasiswa sehingga beberapa agenda dalam khidmat masyarakat yang direncanakan terkadang tidak selesai tepat waktu. Adapun solusinya adalah 
mengajak pemuda desa dan anak-anak untuk bergerak dan ikut membantu dalam kegiatan ini.

Kegiatan ini berjalan lancar dan rutin dilaksanakan setiap pagi hingga menjelang siang dan terkadang berlanjut hingga sore. Bangunan yang dulunya tidak layak huni, kini beberapa di antaranya telah selesai direnovasi berkat adanya kegiatan ini. Kegiatan ini merupakan kegiatan yang sangat diapresiasi oleh masyarakat karena denganya terbangun silaturahmi antara masyarakat dan mahasiswa KKN.

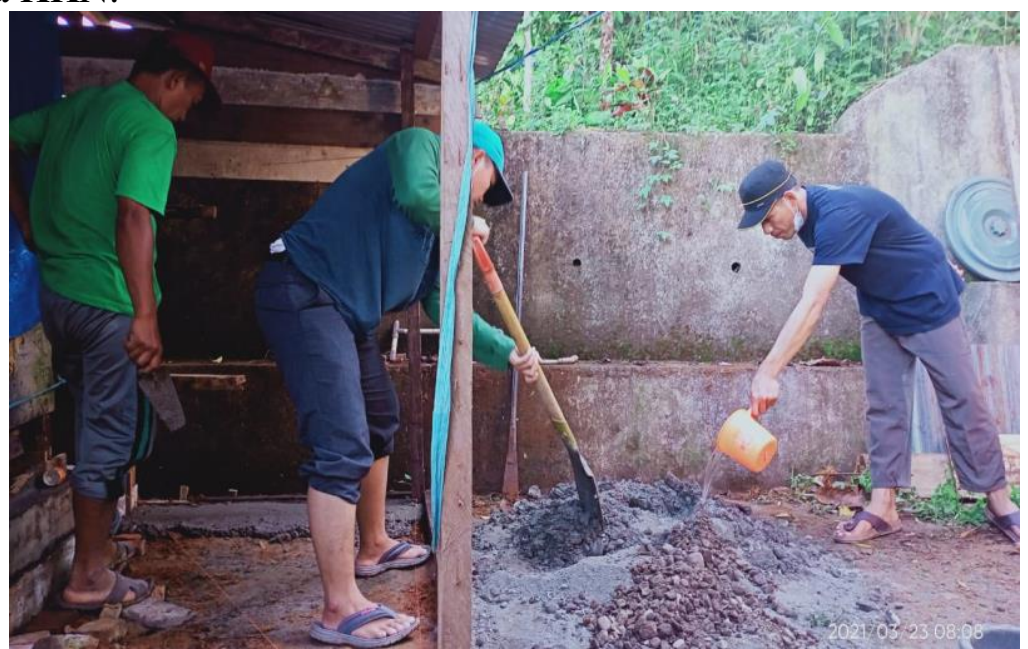

Gambar 3. Khidmat Masyarakat

\section{Silaturahim dan Sosialisasi Program KKN}

Kegiatan ini diawali dengan jalan kaki ke setiap sudut lorong Desa Kabiraan yang dilaksanakan sekali sepekan dengan memperkenalkan Kampus STIBA Makassar dan agenda-agenda mahasiswa selama KKN. Program ini juga biasanya dirangkaikan dengan program Khidmat Masyarakat. Faktor pendukung kegiatan ini adalah keramahan masyarakat dalam menyambut kedatangan mahasiswa yang ingin bersilaturahmi. Adapun kendala yang didapatkan adalah beberapa mahasiswa kurang memahami bahasa masyarakat setempat sehingga mahasiswa agak kesulitan membangun komunikasi. Solusinya adalah menjadikan mahasiswa yang berasal daerah tersebut atau memahami bahasa masyarakat setempat sebagai juru bicara.

Kegiatan ini berjalan lancar, bahkan mampu menjadikan hubungan antara warga desa dengan mahasiswa KKN semakin erat. Bahkan setelah berjalannya waktu, warga sudah sangat mengenal mahasiswa KKN yang berada di Desa Kabiraan. Jika pada awalnya kebanyakan masyarakat masih enggan dan malu menegur terlebih dahulu, kini mereka mulai menyapa. Selain itu, warga Desa Kabiraan juga tidak segan-segan memberikan makanan untuk mahasiswa. Sebelum berakhirnya masa KKN, masyarakat sangat bersedih dan berharap masa KKN dapat diperpanjang karena masyarakat mulai simpati terhadap mahasiswa.

\section{Pembinaan TK/TPA}

Taman Pendidikan Al-Qur'an (TPA) adalah suatu lembaga pendidikan non formal yang bergerak dalam bidang pendidikan. Tujuan diadakannya kegiatan ini 
adalah membantu anak-anak dalam membaca, cara salat yang benar dan memperdalam pengetahuan tentang agama Islam. Adapun metode yang digunakan mahasiswa dalam kegiatan ini adalah iqra', tahsin, menghafal, dan Dirosa. Pembinaan TK/TPA ini diharapkan mampu menumbuhkan karakter anak-anak sejak dini agar mampu memahami dan mengamalkan Al-Qur'an serta memliki akhlak karimah. ${ }^{8}$

Sebelum belajar, para mahasiswa mengumpulkan santri dalam satu ruangan. Kemudian salah satu mahasiswa memberikan arahan kepada santri, seperti memberikan yel-yel, membaca doa dan memberikan sedikit nasehat kepada santri. Para santri kemudian dibentuk dalam beberapa kelompok dan setiap kelompok ditangani oleh satu mahasiswa. Para mahasiswa diberikan jadwal mengajar di beberapa titik pada waktu setelah salat Subuh, Asar, dan Magrib. Adapun faktor pendukung dalam kegiatan ini adalah terbukanya masyarakat dengan memberikan kesempatan kepada mahasiswa untuk mengajar anak-anak mereka mengaji dan masyarakat sangat merespon baik kegiatan tersebut. Kendala yang dihadadapi mahasiswa adalah kurangnya alat-alat untuk mengajar sehingga mahasiswa hanya menggunakan peralatan seadanya. Banyaknya jumlah anak dan sedikitnya pengajar juga menjadi sebuah kesulitan bagi mahasiswa. Kendala lain yang didapatkan adalah mahasiswa kurang bisa untuk mengontrol anak-anak ketika kegiatan pembelajaran TPA berlangsung. Salah satu sebabnya adalah karena anak-anak suka bermain dan berlarian. Solusi yang diterapkan adalah setiap TPA dibina lebih dari satu mahasiswa atau meminta pendampingan dari masyarakat setempat. Perubahan yang terjadi ketika mahasiswa mengajarkan Al-Qur'an kepada anak-anak adalah mereka semakin pintar membedakan huruf dalam Al-Qur'an dan sebagiannya sudah lancar, bahkan diantaranya ada yang sudah pandai menghafal Al-Qur'an.

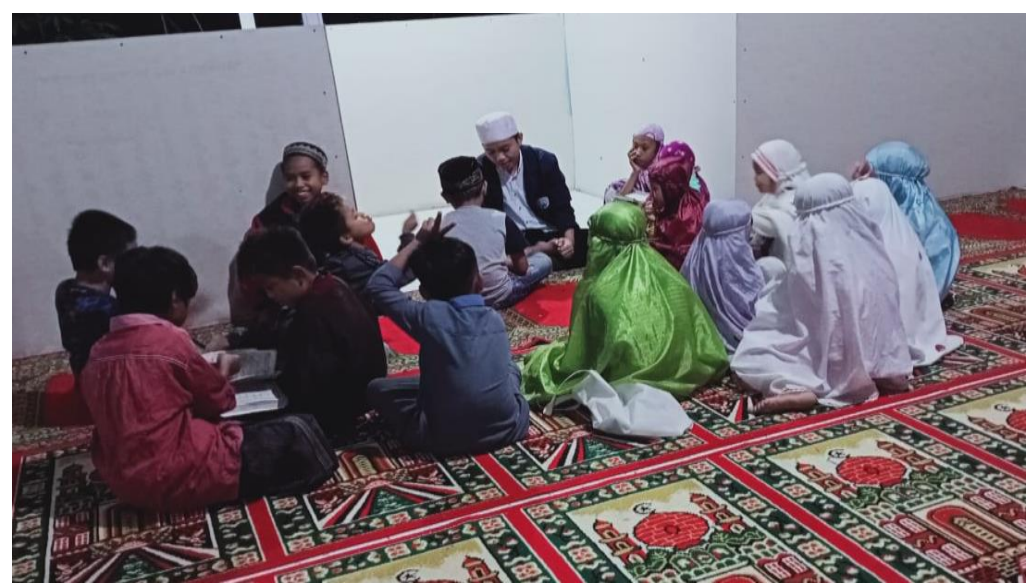

Gambar 4. Pembinaan TK/TPA

\section{Pembuatan Papan Nama Imam Desa dan Batas Antardusun}

${ }^{8}$ Hendra Wijaya, Rosmita, Istikhairiyah Muin. " Program Qur'anic Adventure Mahasiswa KKN STIBA Makassar di Kabupaten Gowa”. WAHATUL MUJTAMA': Jurnal Pengabdian Masyarakat 2, no. 1 (2021): h. 58-69. 
Kegiatan Pembuatan Papan Nama Imam Desa dan Batas Antardusun di Desa Kabiraan adalah kegiatan mahasiswa KKN STIBA yang dilaksanakan pada pekan terkahir KKN yaitu tanggal 24 s.d. 31 Maret 2021, dengan tujuan untuk memudahkan masyarakat mengetahui batas-batas antardusun dan memudahkan masyarakat untuk bersilaturahmi ke rumah Imam Desa. Awalnya, mahasiswa melakukan assessment ke lokasi yang akan dipasangi papan nama, setelah itu dilakukan pembuatan papan nama dari kayu . Adapun sumber dana dalam kegiatan ini berasal dari Wahdah Inspirasi Zakat (WIZ) Majene dibantu dengan dana pribadi mahasiswa. Kendala yang dihadapi adalah mahasiswa kesulitan untuk membuat tulisan pada papan nama karena tidak ada satupun masyarakat yang memiliki alat cetak (printer). Solusinya adalah mahasiswa harus turun ke posko induk WIZ untuk meminjam printer.

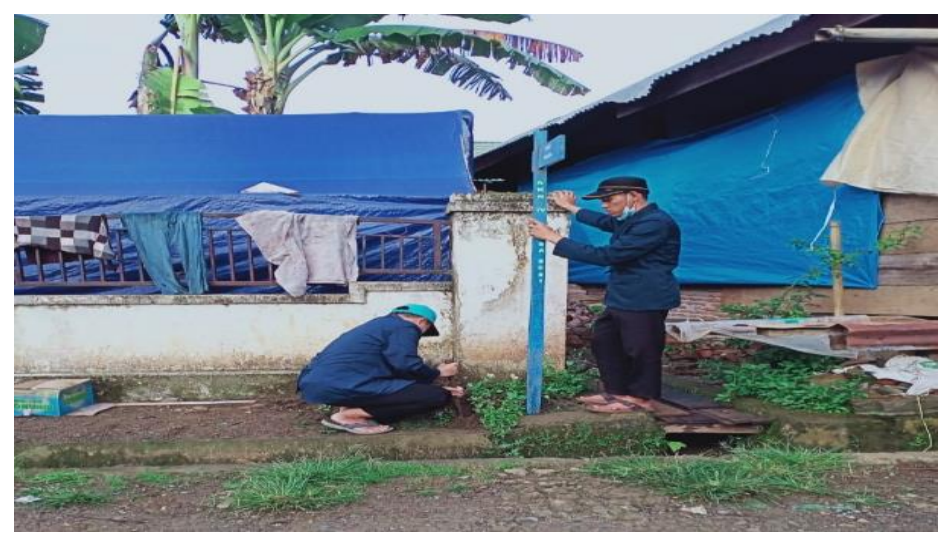

Gambar 5. Pembuatan Papan Nama Imam Desa dan Batas Antardusun

\section{KESIMPULAN}

Berdasarkan hasil pelaksanaan kegiatan Kuliah Kerja Nyata (KKN) Kemanusiaan di Desa Kabiraan, Kecamatan Ulumanda, Kabupaten Majene tanggal 1 Maret 2021 sampai tanggal 1 April 2021, dapat disimpulkan bahwa kegiatan tersebut berjalan dengan baik dan lancar. Mahasiswa mampu dan bersungguhsungguh dalam menghadapi dunia sosial dan mengabdi kepada masyarakat secara nyata, sehingga kedepannya mampu menyelesaikan masalah dalam kehidupan sehari-hari dengan segala ilmu dan pengalaman yang dimiliki. Mahasiswa juga mampu memberikan sumbangan berupa fikiran, pembaharuan, pembinaan, dakwah, dan mentransfer ilmu yang diperoleh di bangku kuliah kepada masyarakat Ulumanda guna peningkatan kualitas hidup dan kemajuan masyarakat khususnya di bidang keagamaan. Seluruh peserta KKN saling membantu satu sama lain dan terus meningkatkan kekompakan, saling melengkapi, memperkuat kerjasama, saling meyumbangkan tenaga, pikiran, dan ilmu yang dikuasai sehingga membentuk pribadi mahasiswa yang mandiri, saling menghormati, berempati dan bertanggung jawab demi keberhasilan program KKN di Desa Kabiraan. Masyarakat Desa Kabiraan sangat terbuka dan mendukung penuh pelaksanaan program KKN Kemanusiaan STIBA Makassar demi pulihnya keadaan masyarakat setelah ditimpa bencana di Desa Kabiraan secara khusus dan Kabupaten Majene secara umum. 
- Jurnal — WAHATUL MUJTAMA': Jurnal Pengabdian Masyarakat

WAHATUL

Seluruh pihak mengharapkan adanya keberlanjutan hasil program KKN Kemanusiaan STIBA Makassar dalam hal pembinaan formal maupun non formal untuk di Desa Kabiraan.

\section{DAFTAR PUSTAKA}

Kirana, Sindy Ayu dan Refy Safitri. "Pengabdian KKN Keluarahan Bukit Betung Menjadi Relawan Covid-19 di Wilayah Bangka Belitung." Prosiding Seminar Hukum dan Publikasi Nasional (Serumpun) II 2 (2020): 461-470.

Nomor. Net. Desa Kabiraan 91454. https://www.nomor.net/_kodepos.php?_i=desa-

kodepos\&sby=000000\&daerah=Desa-Ulumanda\%20(Ulumunda)-Kab.Majene\&jobs=Kabiraan

Prakoso, Dodik Eko. Laporan Akhir Kuliah Kerja Nyata (KKN) Desa Purwasaba Kecamatan Mandiraja Kabupaten Banjarnegara. Prodi Televisi dan Film Fakultas Seni Rupa dan Desain Institut Seni Indonesia Surakarta (2016).

Sam, Zulfiah, Saadal Jannah, dan Sartini Lambajo. "Pelaksanaan KKN Kemanusiaan Mahasiswi STIBA Makassar di Kelurahan Malunda, Kabupaten Majene." WAHATUL MUJTAMA': Jurnal Pengabdian masyarakat 2, no. 2 (2021): 1-10.

Wijaya, Hendra, Rosmita, dan Istikhariyah Muin. "Program Qur'anic Adventure Mahasiswa KKN STIBA Makassar di Kabupaten Gowa." WAHATUL MUJTAMA': Jurnal Pengabdian Masyarakat 2, no. 1 (2021): 58-69.

Wikipedia. Ulumanda, Majene. https://id.wikipedia.org/wiki/Ulumanda,_Majene (Diakses pada tanggal 14 Desember 2021).

Yusuf, Mohammad Bachruddin. "Tanggap Bencana Alam di Dusun Sijati, Desa Sawangan, Kabupaten Porworejo, Provinsi Jawa Tengah” Laporan Pengabdian Masyarakat Kuliah Kerja Nyata (KKN) Pusat Kuliah Kerja Nyata Direktorat Penelitian dan Pengabdian Masyarakat Universitas Islam Indonesia Yogyakarta, 2017. 